\title{
ADVERSE HEALTH EFFECTS AMONG WORKERS IN AN EGYPTIAN LEAD CRYSTAL GLASS MANUFACTURING PLANT
}

\author{
By \\ Mostafa $\mathrm{NS}^{1}$, Mahmoud $\mathrm{NE}^{2}$ and Elhosseiny $\mathrm{D}^{1}$ \\ ${ }^{1}$ Department of Community, Environmental and Occupational Medicine, ${ }^{2}$ Department of Internal \\ Medicine, Faculty of Medicine, Ain Shams University, Cairo, Egypt. \\ Corresponding author: Mostafa NS: Nayera_samy@med.asu.edu.eg
}

\begin{abstract}
Introduction: Glass production workers are exposed to several workplace factors that may affect their health. Lead encountered in the manufacture of crystal glass is known to cause harmful effects. It is necessary to highlight the health effects of lead among Egyptian crystal glass workers. Aim of work: The aim of the study was to identify some health disorders in relation to blood lead level (BLL) among Egyptian workers exposed to lead in a lead crystal glass factory and find the association between (BLL) and psychological morbidities and biochemical parameters. Materials and methods: A comparative cross-sectional study was carried out in the occupational health clinic at Faculty of Medicine, Ain Shams University. It included 50 workers from a lead crystal glass manufacturing plant (exposed group) and 50 non-exposed workers. Data collected included personal data, occupational and medical histories, clinical examination and body mass index (BMI). Blood lead level (BLL), serum calcium, serum uric acid, red blood cell (RBC) count, haemoglobin, serum creatinine, and blood urea nitrogen (BUN) were measured for both groups. A general health questionnaire was used to assess psychological morbidities. Results: Exposed workers and controls were matched for gender and age. Exposed workers had significantly more gastro-intestinal, neurological, heat-related, ear and nose symptoms. Regarding biochemical parameters, BLL, blood urea nitrogen (BUN) were significantly higher among exposed workers, while serum creatinine was higher among non-exposed workers. Psychological distress was statistically significantly more prevalent among exposed workers and the difference was statistically significant. Among the exposed workers, only $60 \%, 56 \%, 56 \%$ and $26 \%$ used gloves, masks, uniform and boots, respectively. Conclusion: Elevated BLL is associated with higher BUN and psychological morbidity among exposed workers.
\end{abstract}

Key words: Blood lead, Lead crystal glass factory, Gastro-intestinal, Neurological, Heat-related, Ear and nose symptoms. 


\section{Introduction}

Glass is a transparent or translucent material that has no crystalline structure and behaves like a solid (Cambridge English Dictionary, 2005). There are five main sectors in the glass manufacturing industry: flat glass, containers and pressed ware, art glass, special glass (e.g. optical and electronic) and fibre glass (Werner, 1994). In the glass industry, the materials used are feldspar, dolomite, salt cake, soda, silica and others. In fact $96 \%$ of glass is made of silica. In the production of heavy crystal glass, the glass batch contains about 30\% lead (Andersson, 1990). Crystal glass as a term is actually misleading as the structure of glass is non-crystalline. The term gained traction mostly for commercial purposes, to accentuate the beauty and special properties of lead glass, which is capable of amazing refraction and seems pseudo-crystal (Tait, 1991).

Occupational lead toxicity was first reported in $200 \mathrm{BC}$ although it is believed it goes back to $2500 \mathrm{BC}$. Lancereaux was the first to report leadrelated nephrotoxicity in 1862 . There were many reports regarding the relation between occupational lead exposure and nephritis in the following decades, which made lead nephropathy as a common diagnosis (Muntner, 2003).
Because of the lately discovered health effects, many glass manufacturers have discontinued production of lead glass or have modified their production to so-called unleaded crystal glass, in which lead oxide is substituted by other oxides (barium oxide, potassium oxide, or zinc oxide) (Davison, 2003). However, in Egypt, the manufacture of leaded crystal glass is still prevalent. In fact, Egyptian lead crystal glass (made with $24 \%-30 \%$ lead oxide) is some of the finest refractive crystal glass. Though not as expensive as Strass or Swarovski crystal, this crystal glass is characterized by a prismatic brilliance, visual purity, sharp faceting and precise polishing (Shades of light, 2017).

Unfortunately, Egyptian workers in such factories are at risk of being exposed to different factors such as contact with toxic materials and harmful chemicals or harmful physical factors. During preparing materials, glass melting process and preparation of the final products, workers are exposed to inhaling free silica dust, lead dust and fumes, irritating alkaline gas or vapour due to combustion and melting materials, working in a hot weather, contact with infrared radiation and finally the danger of touching the 
cutting pieces and glasses, etc... (AbdelRasoul et al., 2013).

The health hazards of glass manufacture have been listed in the International Labour Organization Encyclopaedia of Occupational Health and Safety. Morbid conditions in glass factory workers are injuries, heat exhaustion, respiratory morbidity, ophthalmic and renal morbidity (Lockey et al., 2011). Lead encountered in the manufacture of crystal glass is also known to cause harmful effects in the haematopoietic, nervous, digestive, renal, and other organ systems, inhibiting a number of enzymes in the biosynthesis of haem, as well as other enzymes with haematological significance (Bilban, 2015).

Anaemia caused by lead exposure is the result of the inhibition of haemosynthesis and aggravated failure of erythrocytes. In the case of minor build-up, changes in the kidneys are quite reversible, as early effects are mostly concentrated on the proximal tubules. A higher degree of exposure, however, leads to interstitial fibrosis and advanced renal failure (Patocka, 2008). It is postulated that lead affects the renin-angiotensin system, thus causing increased blood pressure (Hegazy et al., 2010).
Some previous studies dealt with morbidities of glass factory workers. An Indian study conducted in 2016 revealed that, among the glass workers, $33.04 \%$ had prick injuries, $14.91 \%$ musculoskeletal problems, $10.81 \%$ burns, 9.64\% had hypertension, and $5.26 \%$ had ENT problems like noise-induced hearing defects and earache. Ocular injuries were reported by $4.09 \%$, while $3.8 \%$ had chronic irritant cough, difficulty in breathing, and chest pain (Potdar, 2016). In Egypt, a study conducted in 2013 reported that glass workers had a significantly higher prevalence of chest, auditory and heat-related manifestations as well as deteriorated spirometric measurements and abnormal audiometric findings (Abdel-Rasoul et al., 2013).

This study is important as it will highlight the adverse health effects among Egyptian lead crystal glass workers and to provide effective recommendations to support their health.

\section{Aim of work}

To identify some health disorders in relation to blood lead level (BLL) among Egyptian workers exposed to lead in a lead crystal glass factory and find the association between BLL and psychological morbidities and biochemical parameters. 


\section{Materials and methods}

Study design: This is a comparative cross-sectional study.

Place and duration of the study: It was carried out in the occupational health clinic at Faculty of Medicine, Ain Shams University, from October to December, 2017.

Study sample: It included 50 males working at a lead crystal glass producing plant located in Greater Cairo Governorate who were scheduled to be subjected to periodic medical examination. Fifty workers from a public university with no history of job-related exposure to lead were matched by age and gender; were taken as controls.

Exclusion criteria: Workers who had any chest diseases, skin diseases, psychological disorders, cataract or any auditory diseases before employment in this factory were excluded from the study. A sample of 40 was calculated using morbidity prevalence among workers in a glass factory in India equals to $97 \pm 8 \%$ and confidence interval of 95\% (Brahmapurkar, 2013). The sample was calculated using Epi Info 2002 program. It was increased to include 50 exposed workers and 50 non-exposed ones.

\section{Study Methods}

1) A pre-designed interview questionnaire was used to record demographic data, occupational history (including years of working in the industry and use of protective devices), medical history of chest and auditory diseases, manifestations of heat stroke, heat exhaustion, heat cramps, sterility, cataract, skin rash and clinical manifestations of lead poisoning as well as past history of other diseases (mental, nervous diseases, hypertension, diabetes mellitus, liver and kidney diseases or use of antipsychotic drugs and skin, chest or eye allergies).

2)Psychologicaldistresswas measured with the 12-item General Health Questionnaire (GHQ-12), using the original GHQ rating method (00-1-1) (Makowska et al., 2002). The questions ask about self-confidence, mood, sleep disorders, ability to concentrate and problem solving abilities. Points were summed up to a score ranging from $0-12$, which was used as a continuous variable. Based on the optimal cut-off point of $3 / 4$, participants were categorized as non-distressed (GHQ-score: 0-3) and distressed (GHQ-score: 4-12). 
3) General examination was done including: Weight, height and blood pressure measurement. The mean of 3 blood pressure measurements was used, all of which were taken by the researcher using a mercury sphygmomanometer. Patients were categorized as hypertensive if their systolic blood pressure was 140 $\mathrm{mm} \mathrm{Hg}$ or higher, or diastolic blood pressure was $90 \mathrm{~mm} \mathrm{Hg}$ or higher (WHO, 2005).

\section{4) Laboratory investigation:}

Venous blood samples were collected from all exposed and non-exposed workers $(5 \mathrm{~mL})$ in the morning between 7 a.m. and 8 a.m. to determine the levels of haemoglobin, hematocrit, red blood cell (RBC) count, and BLL, blood calcium level, blood urea nitrogen (BUN), serum creatinine and uric acid. The time schedule was adjusted, so that workers could participate in the study conveniently.

Analysis of bloodleadwas performed using Buck Model 210 VGP Atomic Absorption Spectrophotometer in the occupational unit laboratory at Faculty of Medicine, Ain Shams University. Other laboratory investigations were carried out in the central laboratory of Ain Shams University hospital. Reference values of the laboratory were used. The upper limit for normal lead level was $20 \mu \mathrm{g} / \mathrm{dL}$, and elevated levels more than $40 \mu \mathrm{g} / \mathrm{dL}$ were considered cases with lead toxicity that necessitated restriction from work according to OSHA guidelines (CDC, 2018).

\section{Consent}

All subjects were informed about the study objectives and consent was given prior to the study.

\section{Ethical approval}

The study was approved by Faculty of Medicine, Ain Shams University, Committee for Medical Research Ethics.

\section{Data management}

Data were coded and presented to a personal computer. Data were analysed using SPSS statistical package version 20. Qualitative data were presented as frequency and percentages. Quantitative variables were presented as Mean \pm Standard deviation (SD). Chi squared test was used to compare qualitative variables, while student $\mathrm{t}$ test and ANOVA were used to compare quantitative variables. Significant difference was considered at a $p$ value $<0.05$. 


\section{Results}

Table 1: Socio-demographic and personal characteristics of the studied groups.

\begin{tabular}{|c|c|c|c|c|c|}
\hline Characteristic & $\begin{array}{c}\text { Exposed } \\
\text { workers }(\mathrm{No}=50)\end{array}$ & $\begin{array}{c}\text { Non-exposed } \\
\text { workers }(\mathrm{No}=\mathbf{5 0})\end{array}$ & $\begin{array}{c}\text { Total } \\
(\mathrm{No}=\mathbf{1 0 0})\end{array}$ & $\mathbf{t}$ & $\mathbf{p}$ \\
\hline \multirow[t]{2}{*}{$\begin{array}{l}\text { Age } \\
(\text { Mean } \pm \text { SD })\end{array}$} & $38.12 \pm 4.87$ & $40.22 \pm 6.98$ & $39.17 \pm 6.08$ & -1.744 & 0.084 \\
\hline & No $(\%)$ & No $(\%)$ & No $(\%)$ & $\mathbf{X}^{2}$ & $\mathbf{p}$ \\
\hline $\begin{array}{l}\text { Marital status } \\
\text { Single } \\
\text { Married }\end{array}$ & $\begin{array}{c}0 \\
50(100)\end{array}$ & $\begin{array}{c}4(8) \\
46(92)\end{array}$ & $\begin{array}{c}4 \\
96\end{array}$ & 4.167 & 0.117 \\
\hline $\begin{array}{l}\text { Education\# } \\
\text { Not educated } \\
\text { Educated }\end{array}$ & $\begin{array}{c}5(10) \\
45(90)\end{array}$ & $\begin{array}{l}40(80) \\
10(20)\end{array}$ & $\begin{array}{l}45 \\
55\end{array}$ & 49.495 & \\
\hline $\begin{array}{l}\text { Smoking } \\
\text { Smoker } \\
\text { Non-smoker }\end{array}$ & $\begin{array}{l}17(34) \\
33(66)\end{array}$ & $\begin{array}{l}25(50) \\
50)) 25\end{array}$ & $\begin{array}{l}42 \\
58\end{array}$ & 2.627 & 0.105 \\
\hline $\begin{array}{l}\text { BMI } \\
\text { Normal } \\
\text { Overweight } \\
\text { Obese }\end{array}$ & $\begin{array}{l}16(32) \\
23(46) \\
11(22)\end{array}$ & $\begin{array}{l}10(20) \\
20(40) \\
20(40)\end{array}$ & $\begin{array}{l}26 \\
43 \\
31\end{array}$ & 4.207 & 0.122 \\
\hline $\begin{array}{l}\text { Blood pressure } \\
\text { Hypertensive } \\
\text { Normotensive }\end{array}$ & $\begin{array}{l}12(24) \\
38(76)\end{array}$ & $\begin{array}{l}15(30) \\
35(70)\end{array}$ & $\begin{array}{l}27 \\
73\end{array}$ & 0.457 & 0.499 \\
\hline
\end{tabular}

\#: Educated are those who completed primary education or higher.

\section{**: Highly statistically significant \\ BMI: Body Mass Index}

Table 1 showed that the exposed and the non-exposed workers were matched as regards age. There was no statistically significant difference between both groups regarding marital status, smoking habit, body mass index and blood pressure. As regards education, $80 \%$ of the non-exposed workers did not complete primary education. Regarding personal protective devices, only $60 \%, 56 \%, 56 \%$ and $26 \%$ of the glass factory workers used gloves, masks, uniforms and boots, respectively.

Total work duration of glass factory workers ranged from $2-35$ years $(11.18 \pm 6.2)$ and they worked 8 hours daily for 6 days/week (Untabulated data). 
Table 2: Comparison between exposed and non-exposed workers regarding different symptoms.

\begin{tabular}{|c|c|c|c|c|c|c|}
\hline \multirow[t]{2}{*}{ Symptoms } & \multicolumn{2}{|c|}{$\begin{array}{c}\text { Exposed workers } \\
(\mathrm{No}=\mathbf{5 0})\end{array}$} & \multicolumn{2}{|c|}{$\begin{array}{c}\text { Non-exposed } \\
(\mathrm{No}=\mathbf{5 0})\end{array}$} & \multirow[t]{2}{*}{$\mathbf{X}^{2}$} & \multirow[t]{2}{*}{ p-value } \\
\hline & No & $\%$ & No & $\%$ & & \\
\hline \multicolumn{7}{|c|}{ Gastro-intestinal symptoms } \\
\hline Abdominal colic & 18 & 36 & 0 & 0 & 21.951 & $<0.001 * *$ \\
\hline Constipation & 15 & 30 & 5 & 10 & 6.25 & $0.012 *$ \\
\hline Anorexia & 22 & 44 & 15 & 30 & 2.102 & 0.147 \\
\hline Heartburn & 21 & 42 & 10 & 20 & 5.657 & $0.017 *$ \\
\hline \multicolumn{7}{|l|}{ Respiratory symptoms } \\
\hline Chronic cough & 12 & 24 & 10 & 20 & 0.233 & 0.629 \\
\hline Expectoration & 15 & 30 & 15 & 30 & 0 & 1 \\
\hline Chest tightness & 13 & 26 & 20 & 40 & 2.216 & 0.137 \\
\hline Wheezes & 13 & 26 & 10 & 20 & 0.508 & 0.476 \\
\hline Bronchial asthma & 7 & 14 & 10 & 20 & 0.638 & 0.424 \\
\hline \multicolumn{7}{|l|}{ Neurological symptoms } \\
\hline General weakness & 28 & 56 & 13 & 26 & 10.453 & $0.005 *$ \\
\hline Headache & 24 & 48 & 10 & 20 & 8.734 & $0.003 *$ \\
\hline Nervousness & 27 & 54 & 15 & 30 & 5.911 & $0.015 *$ \\
\hline Tremors & 15 & 30 & 0 & 0 & 17.647 & $<0.001 * *$ \\
\hline Muscle ache & 21 & 42 & 5 & 10 & 13.306 & $<0.001 * *$ \\
\hline Insomnia & 19 & 38 & 5 & 10 & 10.746 & $0.001 * *$ \\
\hline Lack of concentration & 28 & 56 & 5 & 10 & 23.926 & $<0.001 * *$ \\
\hline \multicolumn{7}{|c|}{ Ear and nose symptoms } \\
\hline Irritated nasal mucosa & 13 & 26 & 0 & 0 & 14.943 & $<0.001 * *$ \\
\hline Hearing impairment & 20 & 40 & 15 & 30 & 1.099 & 0.295 \\
\hline
\end{tabular}




\begin{tabular}{|l|c|c|c|c|c|c|}
\hline Tinnitus & 14 & 28 & 0 & 0 & 16.279 & $<\mathbf{0 . 0 0 1 * *}$ \\
\hline Earache & 13 & 26 & 0 & 0 & 14.943 & $<\mathbf{0 . 0 0 1 * *}$ \\
\hline related manifestations-Heat & 11 & 22 & 0 & 0 & 12.36 & $<\mathbf{0 . 0 0 1 * *}$ \\
\hline Heat rash & 9 & 18 & 0 & 0 & 9.89 & $\mathbf{0 . 0 0 2 *}$ \\
\hline Muscle twitches & 16 & 32 & 5 & 10 & 7.294 & $\mathbf{0 . 0 0 7 *}$ \\
\hline Heat exhaustion & 7 & 14 & 5 & 10 & 0.379 & 0.538 \\
\hline Cataract & 11 & 22 & 0 & 0 & 12.360 & $<\mathbf{0 . 0 0 1 * *}$ \\
\hline Infertility & & & 0
\end{tabular}

*: Statistically significant

**: Highly statistically significant

Table 2 showed that there was highly statistically significant difference between exposed and non-exposed as regards abdominal colic, constipation, heartburn, all the neurological symptoms asked about, ear and nose symptoms except hearing impairment, heat-related symptoms except cataract, and none of the respiratory symptoms.

\section{Table 3: Comparison between exposed and non-exposed workers regarding biochemical parameters.}

\begin{tabular}{|c|c|c|c|c|c|}
\hline \multirow[t]{2}{*}{ Biochemical parameters } & $\begin{array}{c}\text { Exposed workers } \\
(\mathrm{No}=50)\end{array}$ & $\begin{array}{c}\text { Non-exposed workers } \\
(\text { No }=\mathbf{5 0})\end{array}$ & Total & \multirow[t]{2}{*}{$\mathbf{t}$} & \multirow[t]{2}{*}{ p-value } \\
\hline & \multicolumn{3}{|c|}{ Mean \pm SD } & & \\
\hline $\begin{array}{l}\text { Blood lead level (BLL) } \\
(\mu \mathrm{g} / \mathrm{dL})\end{array}$ & $28.24 \pm 8.64$ & $14.2 \pm 4.78$ & $21.22 \pm 9.9$ & 10.05 & $<0.001 * *$ \\
\hline $\begin{array}{l}\text { Blood urea nitrogen } \\
(\mathrm{BUN})(\mathrm{mg} / \mathrm{dL})\end{array}$ & $23.34 \pm 4.32$ & $15.2 \pm 3.96$ & $19.27 \pm 5.81$ & 9.826 & $<0.001 * *$ \\
\hline Creatinine (mg/dL) & $0.68 \pm 0.122$ & $0.96 \pm 0.12$ & $0.82 \pm 0.19$ & -11.669 & $<0.001 * *$ \\
\hline Serum uric acid (mg/dL) & $4.7 \pm 0.8$ & $5.07 \pm 1.91$ & $4.88 \pm 1.47$ & -1.268 & 0.208 \\
\hline Blood haemoglobin $(\mathrm{g} / \mathrm{dL})$ & $14.21 \pm 1.47$ & $14.27 \pm 1.13$ & $14.24 \pm 1.31$ & -0.244 & 0.808 \\
\hline Red blood cell (per $\mu \mathrm{L})$ & $4.97 \pm 0.45$ & $5 \pm 0.38$ & $4.98 \pm 0.41$ & -0.320 & 0.75 \\
\hline $\begin{array}{l}\text { Total serum calcium (mg/ } \\
\mathrm{dL})\end{array}$ & $8.78 \pm 0.42$ & $8.88 \pm 0.26$ & $8.83 \pm 0.35$ & -1.463 & 0.147 \\
\hline
\end{tabular}

**: Highly statistically significant 
Regarding the biochemical parameters, Table 3 showed that BLL, and BUN were statistically significantly higher among exposed workers. However, serum creatinine level was higher among non-exposed group. The differences between exposed and non-exposed workers regarding serum uric acid, haemoglobin, RBC count and total serum calcium were not statistically significant.

Table 4: Comparison between exposed and non-exposed workers regarding GHQ-12

\begin{tabular}{|l|c|c|c|c|c|}
\hline Variables & $\begin{array}{l}\text { Exposed } \\
\text { workers } \\
\mathbf{( N o = 5 0 )}\end{array}$ & $\begin{array}{c}\text { Non-exposed } \\
\text { workers } \\
\mathbf{( N o = 5 0 )}\end{array}$ & Total & t test/ X & p-value \\
\hline $\begin{array}{l}\text { Score of GHQ (group) } \\
\text { Mean } \pm \text { SD }\end{array}$ & $3.2 \pm 2.62$ & $1.4 \pm 1.58$ & $2.3 \pm 2.33$ & 4.163 & $<\mathbf{0 . 0 0 1 * *}$ \\
\hline $\begin{array}{l}\text { Distressed (GHQ>3) } \\
\text { No (\%) }\end{array}$ & $18(36)$ & $5(10)$ & 23 & 9.543 & $\mathbf{0 . 0 0 2 *}$ \\
\hline
\end{tabular}

GHQ-12:General Health Questionnaire-12

*: Statistically significant

**: Highly statistically significant

Table 4 showed that among exposed workers, there were statistically significantly more distressed workers (18 vs 5).

No statistically significant correlation was detected between years of work in the glass industry and levels of biochemical parameters except creatinine (Pearson correlation coefficient 0.496 , P value $<0.001$ ) (Untabulated data).

\section{Discussion}

Results of this work indicate that BLL is associated with many symptoms and diseases, affecting various body systems.

Regarding gastrointestinal tract (GIT) symptoms, abdominal colic was significantly more prevalent among exposed workers affecting $36 \%$ versus none in non-exposed group (Table 2). This is similar to the results detected by Hwang et al. (1991) on his study on the relationship between blood lead and lead related symptoms among group of workers in Korea.

Constipation and heart burn were also significantly more prevalent among 
the exposed workers compared with the non-exposed (Table 2). Case reports of some patients who were exposed to lead at work reported GIT symptoms including constipation (Shiri et al., 2007)

There was no significant increase of respiratory symptoms among workers in the lead crystal glass manufacturing plant in this study; being evaluated by history taking about chronic cough, expectoration, chest tightness, wheezes or asthma (Table 2). Abdel-Rasoul et al. (2013) reported that respiratory manifestations (rhinitis, cough, expectoration and dyspnoea) and deteriorated spirometric measurements were significantly more prevalent among exposed group of Egyptian workers in a glass industry. This controversy may be related to the type of exposure to irritants in different glass factories.

The relation between lead exposure and nervous system was obvious in this study, as there is highly statistically significant increase of reporting tremors (30\% in exposed and none in nonexposed group), muscle aches (42\% in exposed vs $10 \%$ in non-exposed) and lack of concentration $(56 \%$ in exposed vs $10 \%$ in non-exposed) (Table 2).
Other symptoms like general weakness, headache and nervousness; were significantly higher among the exposed group (Table 2). Those symptoms were reported by Papanikolaou et al. (2005) in their study on workers exposed to lead.

Regarding auditory manifestations due to lead exposure, there were highly statistically significant differences between exposed and non-exposed groups regarding tinnitus and earache. Twenty percent of the exposed group complained of tinnitus and the same percentage had earache in comparison to none in the non-exposed group (Table 2). Potdar et al. (2016) reported that earache and noise-induced hearing defects, at Puducherry glass manufacturing plant, were noticed in $5.26 \%$ of workers. Abdel-Rasoul et al. (2013) found that the exposed group experienced a significantly higher prevalence of all auditory manifestations (hearing loss, tinnitus and earache) and auditory findings (moderate to severe hearing impairment and V- dip) especially at the furnace sector. Nelson et al. (2005) also found that $16 \%$ of the disabling hearing loss in adults was attributed to occupational noise.

Regarding heat-relatedmanifestations, 
heat rash was highly significantly observed among exposed versus nonexposed workers $(22 \%$ versus $0 \%)$. Heat exhaustion and muscle twitches were significantly related to exposed group too (32\% and $18 \%$ respectively in exposed group versus $10 \%$ and $0 \%$ in non-exposed group) (Table 2). In a cross sectional study done by Sripaiboonkij et al., 2009 on respiratory and skin health among glass microfiber production workers; they reported heat exhaustion among $28.1 \%$, heat cramps among $22.0 \%$, heat hyperpyrexia among $2.6 \%$, indicating significant occurrence of heat stress among glass factory workers. AbdelRasoul et al. (2013) reported that heatrelated manifestations (exhaustion cramps and skin rash) were more frequent among exposed glass workers especially at batch and finishing departments with a highly significant relation when compared to non-exposed group. This is in agreement with the studies carried out by El-Safty et al. (2008) in Egypt and by Kishor et al. (2012) in India.

The current work showed that there was no significant difference between exposed and non-exposed groups in relation to cataract (Table 2). Lydhal (1984) studied infrared radiation and cataract in age group of 70 years and older and found that statistically significant increase of all types of cataract, sub-capsular, cuneiform and nuclear compared to comparison group and he concluded that occupational infrared radiation exposure of glass workers accelerates the development of senile changes in the lens. This controversy may be due to different age range in our study than in their study.

It was found that $22 \%$ of the workers and none of the non-exposed group were infertile and the difference was highly significant (Table 2). Causes of reproductive dysfunction and infertility has been previously described in a review on males exposed to lead at the workplace, including oligozoospermia, decrease in sperm density and motility, abnormal sperm head morphology, decreased serum testosterone and hypogonadism (Queiroz and Waissmann, 2006).

In the current study, haemoglobin and RBC count showed slight nonsignificant decrease among exposed workers vs non-exposed ones (Table 3). In controversy, Hwang et al. (1991) in their study on the relationship between blood lead and lead-related 
symptoms in low level lead exposure; found statistically significant difference between exposed and non-exposed regarding haemoglobin level. This may be explained by the small sample size of the current study.

BUN was significantly higher among the exposed versus non-exposed (Table 3). In the United States; hypertension, and exposure to lead, even at low levels were associated with chronic kidney disease as reported by Muntner et al. (2003). Blood lead concentrations were higher among adults with renal failure and had a history of childhood lead poisoning as reported by Emmerson (1991). Investigators from the Cadmibel Study Group on their study on impairment of renal function with increasing blood lead concentrations in the general population found an association between blood lead and impairment in renal function among the general population in Belgium (Staessen et al., 1992).

Regarding psychological distress among glass factory workers, our work showed highly significant association between distress (GHQ>3) and lead exposure $(36 \%$ in exposed versus $10 \%$ in non-exposed) (Table 4). In line with this result, Jeyaratnam et al.
(1986) also reported significantly more complaints of anxiety and depression, poor concentration and forgetfulness, and some somatic complaints among lead-exposed workers in Singapore.

Conclusion: Lead crystal glass industry is significantly associated with high levels of BLL, BUN and psychological distress. Negligence of using personal protective devices is evident among the studied group of workers.

\section{Conflict of interest}

The authors report no conflict of interest.

\section{Funding}

None

\section{References}

1. Abdel-Rasoul GM, Al-Batanony MA, AbuSalem ME, Taha AA and Unis F (2013): Some health disorders among workers in a glass factory. Occup Med Health Aff; 1: 106. doi:10.4172/2329-6879.1000106

2. Andersson L, Wingren $\mathrm{G}$ and Axelson $\mathrm{O}$ (1990): Some hygienic observations from the glass industry. Int Arch Occup Environ Health; 62: 249-52.

3. Bilban M (2015): Health impact of elevated levels of lead encountered in the manufacture of crystal glass. Coll Antropol; 39 (4): 915-22.

4. Brahmapurkar KP, Lanjewar AG, Zodpey SP, Shrote VK, Khan, QH et al. (2013): Morbidities in the glass factory workers of Central India. IOSR-JDMS; 7 (6): 29-33. 
5. Cambridge English Dictionary (2005): [Accessed on 1/11/2018]. Available at: https:// dictionary.cambridge.org/dictionary/english/ glass

6. Centre for Disease Control (CDC). Adult blood lead epidemiology and surveillance (ABLES) (2018): [Accessed on 20/10/2018]. Available at: http://www.cdc.gov/niosh/topics/ables/ description.html

7. Davison S (2003): Conservation and restoration of glass. Butterworth- Heinemann

8. [Accessed on 20/10/2018].Available at: https:// www .academia.edu/3386155/Conservation_ and_Restoration_of_glass_Sandra_Davison

9. El-Safty A, Salem M, Abdel-Maksoud N and Helal S (2008): Cardiovascular manifestations in glass industry. Egypt J Occup Med; 32: 23953.

10. Emmerson BT (1991): Lead stores in patients with renal insufficiency. Nephron; 58: 233-4.

11. Hegazy AA, Zaher MM, Abd el-Hafez MA, Morsy AA and Saleh RA (2010): Relation between anaemia and blood levels of lead, copper, zinc and iron among children. BMC Res Notes; 3: 133. doi: 10.1186/1756-0500-3-133.

12. Hwang KY, Ahn JE, Ahn KD and Lee BK (1991): Relationship between blood lead and lead-related symptoms in low level lead exposure. Korean J Prev Med; 24(2):181-94.

13. Jeyaratnam J, Boey KW, Ong CN, Chia CB and Phoon WO (1986): Neuropsychological studies on lead workers in Singapore. Br J Ind Med; 43(9): 626-9.

14. Kishor PB, Ashok GL, Sanjay PZ, Vaishali KB, Gautam MK, et al. (2012): Heat stress and its effect in glass factory workers of central India. Int J Eng Res Technol ; 1: 1-13.

15. Lockey, James ER and Clara S (2011): Health effects of man-made fibres. Volume I. Encyclopedia of Occupational Health and Safety (4th edition). International Labour Organization. Edited by Stellman JM. [Accessed on 1/1/2019]. Available at: http:// iloencyclopaedia.org/part-i-47946/respiratory- system/21-10-respiratory-system/healtheffects-of-man-made-fibres.

16. Lydhal E (1984): Infrared radiation and cataract. Acta Ophthalmol. 16: 61-3 [Abstract from Medline].

17. Makowska Z, Merecz D, Mościcka A and Kolasa W (2002): The validity of general health questionnaires, GHQ-12 and GHQ-28, in mental health studies of working people. Int $\mathbf{J}$ Occup Med Environ Health; 15(4): 353-62.

18. Muntner P, He J, Vupputuri S, Coresh J and Batuman V (2003): Blood lead and chronic kidney disease in the general United States population: results from NHANES III. Kidney Int; 63: 1044-50.

19. Nelson DI, Nelson RY, Concha-Barrientos M and Fingerhut M (2005): The global burden of occupational noise-induced hearing loss. Am J Ind Med; 48: 446-58.

20. PapanikolaouNC, Hatzidaki EG, Belivanis S, Tzanakakis GN and Tsatasakis AM (2005): Lead toxicity update. A brief review. Med Sci Monit; 11(10): 329-36.

21. Patocka J (2008): Organic lead toxicology. Acta Medica (Hradec Králové); 51: 209.

22. Potdar PA, Potdar AB, Thillana P and Deivamani (2016): Study of occupational health problems among workers in a glass manufacturing plant at Puducherry. Medico-Legal Update J; 16 (1): 34-8.

23. Queiroz EK and Waissmann W (2006): Occupational exposure and effects on the male reproductive system. Cad. Saúde Pública, Rio de Janeiro, 22(3):485-93.

24. Shades of Light (2017): Types of crystal. [Accessed on 1/11/2018]. Available at: https:// www.shadesoflight.com/blog_entries/types-ofcrystal

25. Shiri R, Ansari M, Ranta M and Falah-Hassani $K$ (2007): Lead poisoning and recurrent abdominal pain. Ind Health; 45:494-6.

26. Sripaiboonkij P, Sripaiboonkij N, Phanprasit W and Maritta SJ (2009): Respiratory and skin health among glass microfiber production 
workers: a cross-sectional study. Env Health; 8: 36. doi:10.1186/1476-069X-8-36.

27. Staessen JA, Lauwerys RR, Buchet JP, Bulpitt CJ, Rondia D, et al. (1992): Impairment of renal function with increasing blood lead concentrations in the general population. The Cadmibel Study Group. N Engl J Med; 327: 151-6. doi:10.1056/NEJM199207163270303.

28. Tait H (1991): Five Thousand Years of Glass.
British Museum Press. ISBN 0714117161

29. Werner V (1994): Glass Chemistry (2nd ed). ISBN 9783642787232.

30. World Health Organization, Regional office for the Eastern Mediterranean Cairo (2005). Clinical guidelines for the management of hypertension. 